\title{
PENSAR E POETAR O (IN)ÚTIL: HEIDEGGER E MANOEL DE BARROS *
}

\author{
Thinking and Poetizing the Useless: Heidegger and Manoel de Barros
}

\author{
Angela Luzia Miranda **
}

Resumo:O propósito deste artigo é aproximar o pensar do filósofo Martin Heidegger e o poetar do poeta Manoel de Barros. $O$ fio condutor por onde se construirá a análise tem como problemática a relação entre útil e inútil, presente tanto na filosofia de Heidegger, quanto na poesia de Manoel de Barros. E perpassa a seguinte questão: tomando como ponto de partida a atividade do pensar (meditativo) em Heidegger e a poesia (poética do inútil) em Barros, de que forma é possível situar o pensamento fora da esfera meramente instrumental e utilitarista que, costumeiramente, entendemos fundar toda ação na contemporaneidade? E mais: como a filosofia de Heidegger e a poesia de Manoel de Barros podem trazer luz a este modo de pensar e agir? Quais os traços característicos que aproximam ambos, filósofo e poeta? Esta problemática nos levará a supor que, no caso de Heidegger e Manoel de Barros, o que comunga a filosofia e a poesia vai muito além da linguagem. $O$ caminho empreendido para tal propósito trata da construção argumentativa e comparativa, entrelaçando ambos autores e tendo como

\footnotetext{
* Este artigo, cuja redação final é da autora principal, contou com a colaboração e autoria secundária de Maria Renata de Castro Sulino que, na condição de bolsista de pesquisa, apresentou parte dos resultados prévios deste estudo no Congresso ESOCITE/2017. (Cf. CASTRO SULINO, M. R. de; MIRANDA, A. L. "Pensar o ínfimo: aproximações entre o caráter (in)útil da técnica e o poético". In: Anais VII Simpósio Nacional de Ciência, Tecnologia e Sociedade (ESOCITE/2017). Brasília: Finatec/UNB, 05-07/10/2017, p 1-15).

** Doutora em Filosofia (Universidad de Salamanca/USAL-Espanha e Universidad del País Vasco/UPV-Espanha). Professora Adjunta (Universidade Federal do Rio Grande do Norte/ UFRN-BR). Artigo recebido em 25/05/2018 e aprovado para publicação em 11/07/2018.
} 
fundamentação teórica suas principais obras que permeiam a questão do útil e do inútil, seja do ponto de vista da filosofia ou da poesia.

Palavras-chave: Heidegger. Manoel de Barros. Filosofia. Poesia. Útil e Inútil.

Abstract: This article aims to approach the thinking of the philosopher Martin Heidegger and the poetizing of the poet Manoel de Barros. The guiding thread of the analysis deals with the relationship between the useful and the useless. Both are present in Heidegger's philosophy and Manoel de Barros' poetry. The following question permeates the study: taking as a starting point the activity of (meditative) thinking in Heidegger and poetry (the poetry of uselessness) in Manoel de Barros, how can we place the act of thinking outside the merely instrumental and utilitarian sphere, in which we usually ground all our actions in contemporaneity? Moreover, how can Heidegger's philosophy and Manoel de Barros' poetry bring light to this way of thinking and acting? What are the characteristic traits that approximate both philosopher and poet? This leads us to suppose that what unites philosophy and poetry, as is the case for both Heidegger and Manoel de Barros, goes far beyond language. The path taken here involves an argumentative and comparative construction that interweaves both authors and finds its theoretical foundation in the authors' main works dealing with the question of usefulness and useless, from both a philosophical and a poetical standpoint.

Keywords: Heidegger. Manoel de Barros. Philosophy. Poetry. Usefulness and Uselessness.

\section{Introdução}

Prefiro as máquinas que servem para não funcionar: quando cheias de areia de formiga e musgo - elas podem um dia milagrar de flores (Manoel de Barros).

O mais útil é o inútil (Martin Heidegger).

\footnotetext{
- egundo Martin Heidegger, o pensar próprio da modernidade reside no âmbito do cálculo. Nele, as coisas se apresentam utilitariamente, sendo o "útil" um modo de ser como disposição que se manifesta, sobretudo, no mundo da produção material (poiésis), ao que Heidegger denominava "pensar calculador" [das rechnende Denken $]^{1}$. Portanto, o

${ }^{1}$ Veja-se, em especial, seu escrito, "Gelassenheit" (GA 16). (Cf trad. ao português de Maria Madalena Andrade e Olga Santos, Serenidade. Lisboa: Instituto Piaget, 2001). NOTA: Neste artigo, as obras de Martin Heidegger, citadas do original da edição Obras completas [Gesamtausgabe], serão também indicadas por GA, seguidas do Tomo correspondente e da página, quando couber. Também e quando couber, será indicada, na primeira citação do original, a tradução da obra correspondente ao português.
} 
pensar calculador vincula-se com tudo aquilo que enaltece o sentido da utilidade da ação, incluindo o próprio saber. Afinal, pensar tornou-se sinônimo de "produzir efeitos"2. Apesar do pensar calculador imperar na sociedade moderna, Heidegger postula, em contraposição, um outro modo de pensar, o "pensar meditativo" ou a reflexão meditativa [das besinnliche Nachdenken], que medita sobre o próprio pensar, e não apenas opera em vista do agir racional para uma finalidade calculada. O pensar calculador aparece com toda claridade no modo tecnificado em que vivemos. Daí que se, por um lado, enaltecemos o fazer utilitário, a instrumentalização e a tecnificação das coisas, por outro, desprezamos tudo o que não têm a mesma serventia, o inútil.

$\mathrm{Na}$ esteira do útil e do inútil, também encontramos a poesia de Manoel de Barros. Um poeta brasileiro contemporâneo, que usou e abusou das "coisas ínfimas", tal como ele mesmo diz: "Nasci para administrar o à-toa, o em vão, o inútil" ${ }^{3}$. E, quando indagado sobre o que é a poesia, num documentário intitulado Só dez por cento é mentira, ele observa: "a poesia é a virtude do inútil - não tem nenhuma utilidade!"4.

Da leitura filosófica sobre o sentido do útil e do inútil entre ambos autores (Heidegger e Barros), surge, então, a indagação mais elementar: tomando como ponto de partida a atividade do pensar em Heidegger e a poesia das coisas ínfimas de Manoel de Barros, de que forma é possível o pensamento repousar no caráter inútil das coisas? Como este modo de pensar se apresenta na filosofia de Heidegger e no poetar de Manoel de Barros? Que traços característicos aproximam ambos (filósofo e poeta)? Portanto, o objetivo desse estudo é analisar o in(útil) presente, tanto no pensamento de Martin Heidegger a partir do significado do pensar meditativo, quanto na poesia de Manoel de Barros a partir do sentido das coisas ínfimas. No caso de Heidegger, o perguntar consiste em saber se é possível -perpassando, inclusive, a técnica-, o pensamento repousar essencialmente no caráter inútil das coisas. Ou, dito de outro modo, como o pensamento pode se ocupar de um agir desprovido da ação utilitária. No caso de Manoel de Barros, o trabalho consiste em aclarar como este sentido de ação, órfã de qualquer caráter de utilidade, tem guiado sua poesia, cuja intencionalidade nos conduz à resignificar as coisas ínfimas.

O propósito deste trabalho, portanto, é construir um caminho cuja tarefa do pensar tem como fundamento o "passo atrás" proposto por Heidegger e o significado das "insignificâncias" postulado por Barros. Diante dos

\footnotetext{
${ }^{2}$ HEIDEGGER, M. "Brief über den Humanismus" (GA 9), p. 313. (Cf. trad. ao português de Enio Paulo Giachini e Ernildo Stein, "Carta sobre o humanismo". In: Marcas no Caminho. (Wegmarken). Petrópolis, RJ: Vozes, 2008).

${ }^{3}$ BARROS, M. de. Livro sobre nada. Rio de Janeiro: Record, 1996, p. 51.

${ }^{4}$ BARROS, Só dez por cento é mentira: a desbiografia de Manuel de Barros (Documentário). Direção de Pedro César. Brasil: Artezanato eletrônico, 81'16"', 2008.
} 
argumentos aqui apresentados, suspeitamos, em consequência, que a proximidade entre filosofia e poesia vai muito além da linguagem, posto que ambos projetos, o do filósofo e o do poeta, tratam de encurtar as distâncias rumo ao ser (diria Heidegger), atingindo o estágio das "pré-coisas" (diria Manoel de Barros). Em ambos os casos, sempre enaltecendo o in(útil), assim dito e escrito literalmente, porque indica as duas caras da mesma moeda, tal como veremos. Para atingir tal propósito, primeiramente, trataremos de estabelecer uma leitura biográfica desde o cenário onde nasce o pensar de Heidegger e o poetar de Barros, a fim de situar e identificar similitudes, ainda que guardadas as distâncias geográficas. O passo seguinte consistirá em identificar o sentido do útil e do inútil, relacionando o pensar do filósofo e o poetar do poeta. Por fim, haveremos de nos aproximar do "habitar as coisas ínfimas" de Manoel de Barros, por intermédio do "passo atrás" de Heidegger, como alternativa de superação do pensar calculador.

\section{Do lugar do pensar e do poetar}

"Onde estamos quando pensamos?" A intrigante pergunta de Safranski ${ }^{5}$, ao descrever a biografia de Heidegger, parece indicar também o rumo da nossa questão. E, no caso da poesia, a indagação parece ser a mesma: onde estamos quando poetamos? Ao descrever o contexto de onde nasce o pensar em Heidegger, Miranda observa: "Se a filosofia carece de lugar, ao mesmo tempo, está ligada a um lugar"6. E, da mesma forma que a filosofia de Heidegger estabelece um vínculo desde onde se pensa, Manoel de Barros também canta seus versos desde um lugar evidenciado pela sua poesia. Portanto, antes de chegar no núcleo central deste estudo, é mister circundar o lugar desde onde pensa Heidegger e poetisa Manoel de Barros sobre o útil e o inútil.

O filosofar de Heidegger remete-se às montanhas da Floresta Negra e a sua conhecida cabana de Todtnauberg. “É ali, subtraindo-se da cidade e se afastando da província, em meio à Floresta Negra e na relação direta com o campo e os camponeses, que emergem originariamente os pensamentos e a filosofia de Heidegger"7. É, portanto, rodeado pelas montanhas e pelo

\footnotetext{
${ }^{5}$ SAFRANSKI, R. Un maestro de Alemania. Martin Heidegger y su tiempo. Trad. de Raúl Gabás. Barcelona: Fábula, 2003, p. 325.

${ }^{6}$ MIRANDA, A. L. Técnica y ser en Heidegger. Salamanca: Universidad de Salamanca, 2017, p. 96. ${ }^{7}$ MIRANDA, Técnica y ser en Heidegger. Salamanca: Universidad de Salamanca, 2017, p. 9596. Aqui vale advertir ao leitor -ainda mais aquele desconfiado dos perigos da filosofia de Heidegger e sua relação com a política- que somos conscientes da importância da leitura geopolítica quando se trata de situar o contexto do filósofo alemão. Do mesmo modo que também somos conscientes da polêmica existente na literatura atual sobre a filosofia de Heidegger e sua vinculação política na época do nacional-socialismo. No entanto, neste estudo
} 
campesinato que Heidegger constrói o caminho para o seu pensar filosófico. Esse cenário também fica evidente em um dos seus escritos intitulado Paisagem Criativa: por que permanecemos na província? quando o filósofo recusou o convite da Universidade de Berlin. Já, na parte introdutória, ele descreve o seu mundo de trabalho, a cabana de Todnauberg, onde se levanta seu pequeno refúgio em meio às montanhas nevadas desta parte da Alemanha. Porém, Heidegger adverte que, em realidade, ele não observa a mesma paisagem artificial, vista pelos visitantes recém-chegados ao lugar. Ali ele experimenta a sua profunda transformação, quando a própria existência se encontra arrojada à paisagem, que se torna fonte de criação do seu obrar filosófico. E diz:

Quando, na profunda noite de inverno, uma feroz tempestade de neve ruge pelo abrigo e escurece e esconde tudo, então é a hora propícia da filosofia. Sua pergunta deve se tornar simples e essencial. A elaboração de cada pensamento não pode ser senão árdua e severa. O esforço para cunhar as palavras se assemelha à resistência dos pinheiros na vertical contra a tempestade ${ }^{8}$.

Heidegger também observa que seu trabalho se assemelha ao do camponês que, rebocando o seu trenó de montanha costa acima, carrega-o com troncos de lenha e, uma vez carregado, dirige-se à sua cabana num perigoso descenso. Ou, ao trabalho do pastor de ovelhas que, "com seu andar lentamente meditativo, conduz seu rebanho" ${ }^{\prime \prime}$. Nessa relação direta com o cenário e numa íntima relação com a natureza, também se situa a poesia de Manoel de Barros. No caso do poeta, a "floresta" é a do Pantanal do Mato Grosso, como ele mesmo descreve em sua poesia Auto-Retrato Falado:

(...)

Me criei no Pantanal de Corumbá entre bichos do chão, aves, pessoas humildes, árvores e rios.

Aprecio viver em lugares decadentes por gosto de estar entre pedras e lagartos.

Já publiquei 10 livros de poesia: ao publicá-los me sinto meio desonrado e fujo para o Pantanal onde sou abençoado a garças.

Me procurei a vida inteira e não me achei - pelo que fui salvo.

priorizamos o espaço geográfico desde onde se situa a filosofia de Heidegger e a poesia de Manoel de Barros. Ou seja, sem ignorar a importância do contexto (político), interessa-nos em especial o cenário, em vista do propósito especifico do qual se ocupa este estudo.

${ }^{8}$ HEIDEGGER, "Schöpferische Landschaft: Warum bleiben wir in der Provinz?" (GA 13), p. 10. (Cf. trad. ao português de José Pedro Cabrera, "Por que é que continuamos na província?". In: Escritos políticos 1933-1966. Lisboa: Instituto Piaget, 1997).

${ }^{9}$ HEIDEGGER, “Schöpferische Landschaft: Warum bleiben wir in der Provinz?" (GA 13), p. 10. 
Não estou na sarjeta porque herdei uma fazenda de gado.

Os bois me recriam.

Agora eu sou tão ocaso!

Estou na categoria de sofrer da moral porque só faço

coisas inúteis.

No meu morrer tem uma dor de árvore ${ }^{10}$.

O Pantanal é o lugar onde se encontra o poeta, traduzido e vivenciado no ser-poético de sua poesia. Ali, ele busca compor seus versos com elementos regionais, repleto de questões existenciais, tornando-as perceptíveis em seu próprio fazer poético (ainda que correndo o risco de "sofrer da moral" por pertencer à categoria dos inúteis e por apreciar os "lugares decadentes"). Por meio dos seres que habitam o lugar, o Pantanal é retratado por Barros através da palavra, pela poética, como meio da proximidade de tudo aquilo que ali existe. Na poesia de Manoel de Barros, as coisas adjetivam e os adjetivos coisificam, por isso, se diz do "abençoado a garças", da "dor de árvore", do "milagrar de flores", etc. O mundo metamorfoseado, quase que transfigurado pelo poeta, deixa-se ver na realidade contorcida do "abridor de amanhecer", na "pessoa apropriada para pedras" ou no "esticador de horizontes".

É a partir deste real transfigurado (pelo menos aos olhos dos homens da ciência!) que Manoel de Barros edifica e elege, a partir da sua peculiar linguagem poética, o ordinário, o inútil, o imprestável, e os transforma, com suas "despalavras" repletas de serventia poética, naquilo que serve para a poesia. E, se Martin Heidegger compara a sua filosofia ao trabalho do camponês da Floresta Negra, Manoel de Barros compara sua arte de fazer poesia com o trabalho do roceiro do Pantanal:

\section{O ROCEIRO}

No clarear do dia vou para o roçado

A capinar.

Até de tarde tiro o meu eito: arranco inços tranqueiras, joás e bosta de bugiu que não serve nem pra esterco.

Abro a terra e boto as sementes.

Deixo as sementes para a chuva enternecer.

Dou um tempo.

Retiro de novo as pragas: dejetos de aves, adjetivos.

(Retiro os adjetivos porque eles enfraquecem as plantas)

E deixo o texto a germinar sobre o branco do papel

Na maior masturbação com as pedras e as rãs ${ }^{11}$.

${ }^{10}$ BARROS, O livro das ignorãças. Rio de Janeiro: Record, 1993, p. 107.

${ }^{11}$ BARROS, Poesia completa. São Paulo: Leya, 2010, p. 380-381. 
Enfim, Manoel de Barros tal como Heidegger, parece carregar a ambiguidade existencial do nosso tempo, um tempo que dá o que pensar. E isso por várias razões. A primeira, a qual já tratamos aqui, aparece configurada pelo próprio lugar em que ambos habitam, cuja dicotomia se diz da cidade e do campo, do urbano e do rural, do moderno e do arcaico ou decadente. A segunda razão pelo qual pensador e poeta carregam a ambiguidade dos tempos atuais, diz respeito do que vivem, em que trabalham: ambos parecem condenados a "sofrer da moral", porque vivem de fazer coisas inúteis, seja a poesia ou a metafísica. E a terceira razão, não menos importante para o propósito deste estudo, diz-se da "esquizofrenia" de viver para pensar e poetar sobre o sentido do inútil (ou as insignificâncias do ser), em tempos em que a utilidade faz toda a diferença e é (quase) um sentido existencial. Sobre estas duas últimas razões, haveremos de tratar mais detidamente daqui em diante.

\section{O útil}

\subsection{A ditadura da utilidade e o pensar calculador}

Efetivamente, o que tem mais valor hoje em dia? O abridor de latas, ou o abridor de amanhecer ${ }^{12}$ A engenharia e a física, ou a poesia e a filosofia? $\mathrm{O}$ que o astrônomo nos diz cientificamente sobre as estrelas, ou o que o poeta canta em seus versos? No contexto da sociedade em que vivemos, damos por suposto que algumas coisas valem mais do que outras, porque possuem maior eficiência e eficácia em relação ao fim prático e instrumental a que se propõe, seja do ponto de vista do objeto em si ou do próprio conhecimento sobre o objeto. Daí deriva a nossa compreensão moderna e atual sobre o que é o útil, tal como observa Ordine, em seu manifesto intitulado $A$ utilidade do inútil.

No universo do utilitarismo, em efeito, um martelo vale mais que uma sinfonia, uma faca mais que uma poesia, uma chave inglesa mais que um quadro: porque é fácil assumir a eficácia de um utensílio, enquanto se torna cada vez mais difícil entender para que pode servir a música, a literatura ou a $\operatorname{arte}^{13}$.

\footnotetext{
${ }^{12}$ Expressão presente na poesia "Mundo Pequeno" de Manoel de Barros, ao contar que Bernardo (personagem de várias de suas poesias) guarda num velho baú seus instrumentos de trabalho. Entre eles estão: "1 abridor de amanhecer/ 1 prego que farfalha/ 1 encolhedor de rios e / 1 esticador de horizontes (...)" (BARROS, Poesia completa. São Paulo: Leya, 2010, p. 322). ${ }^{13}$ ORDINE, N. La utilidad de lo inútil. Trad. Jordi Bayod. Barcelona: Acantilado, 2013, p.17-18.
} 
O quadro a seguir também parece insinuar este estado das coisas, porque põe em relevo o valor do útil, revelado na dicotômica relação entre a técnica (o objeto tecnológico, o utensílio) e a arte (o objeto artístico, a obra):

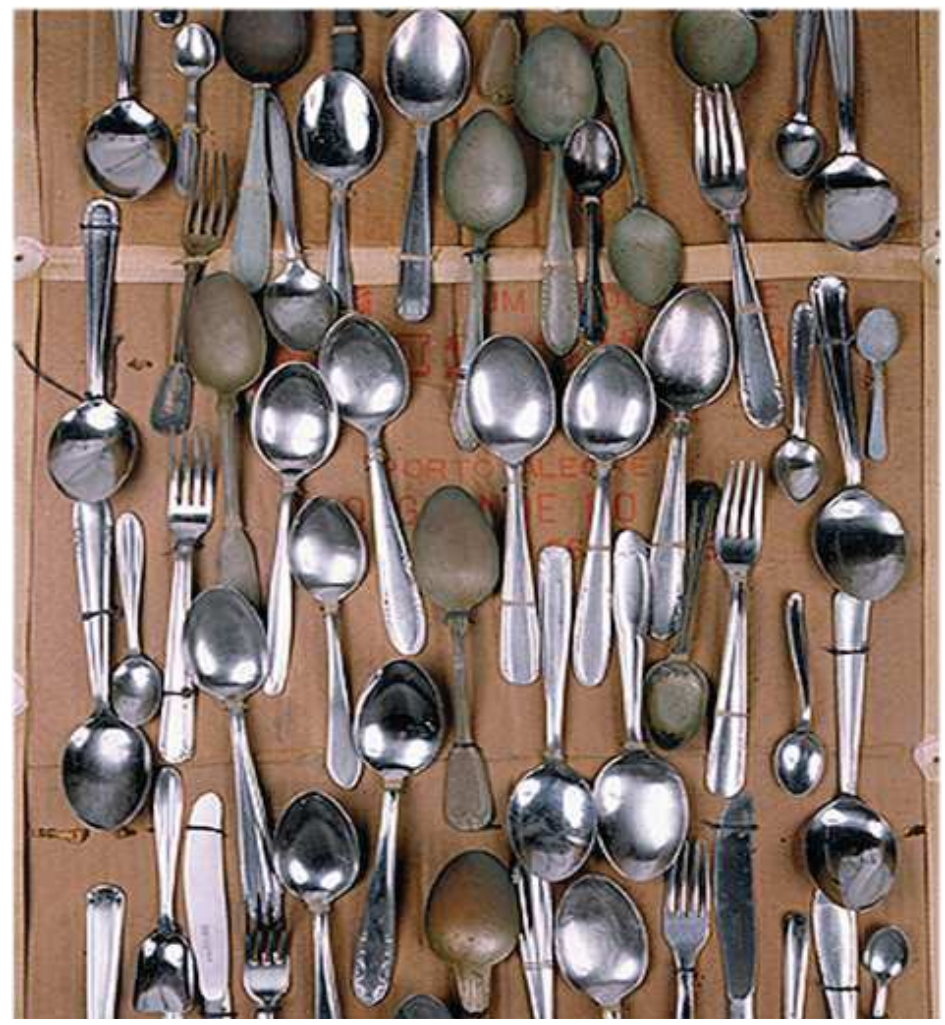

TALHERES (BISPO DO ROSÁRIO) ${ }^{14}$

Antes de prosseguir com a reflexão reveladora da obra, uma advertência: ao questionar o útil, não se pretende aqui declarar sua inexistência, mas sim, evidenciar o quanto o sentido corrente pode ser insuficiente; seja porque se dissimula numa ideologia, ou porque menospreza outros elementos que constituem o seu sentido. No primeiro caso, tal como demonstra Leminski, numa crítica ainda mais ácida sobre a lógica utilitarista da conjuntura atual, tem-se o lucrocentrismo do sistema econômico, ao que ele denomina $A$ ditadura da utilidade:

A burguesia criou um universo onde todo gesto tem que ser útil. (...) $\mathrm{O}$ pragmatismo de empresários, vendedores e compradores, mete preço em cima de tudo. Porque tudo tem que dar lucro. Há trezentos anos, pelo menos, a ditadura da utilidade é unha e carne com o lucrocentrismo de toda essa nossa civilização. E o princípio da utilidade corrompe todos os setores da vida, nos fazendo crer que a própria vida tem que dar lucro. Vida é o dom dos deuses, para ser saboreada intensamente até que a Bomba de Nêutrons ou o vazamento da usina nuclear nos separe deste pedaço de carne pulsante, único bem de que temos certeza ${ }^{15}$.

${ }^{14}$ BISPO do ROSÁRIO, A. "Talheres". In: Itaú Cultural de Arte e Cultura Brasileiras. Disponível em: http://enciclopedia.itaucultural.org.br/obra35996/talheres. Acesso em: Abr. de 2018. ${ }^{15}$ LEMINSKI, P. Ensaios e anseios crípticos. Campinas: Editora da Unicamp, 2012, p. 85. 
Na segunda situação, isto é, na esteira da insuficiência daquilo que costumeiramente designamos como útil, Heidegger observa que se desconsidera uma infinidade de outros elementos que não estão incorporados nesta lógica de compreensão das coisas. Essa tese, contemplada pelo pensador em A origem da obra de arte ${ }^{16}$, quando trata da "coisidade" da coisa, faz todo sentido para o nosso propósito. Sobretudo, quando nos perguntamos sobre o que identifica uma coisa como coisa ${ }^{17}$. Segundo o filósofo, na atualidade, a interpretação preponderante como resposta consiste em situar a coisidade da coisa como matéria compreendida dentro de uma forma. Um sapato, por exemplo. Seu traço característico é a utilidade: "matéria e forma habitam, como determinações do ente, a essência do utensílio"18, cujos entes são produtos de uma elaboração para o uso. Portanto, encontram-se sempre próximo do nosso entorno.

Embora seja o comumente empregado, esse conceito de coisa não revela o ente da coisa em si, mas o do utensílio. Sua aparente inquestionabilidade ocorre graças ao fato de o considerarmos produto da nossa própria criação ${ }^{19}$. Assim, quando perguntamos sobre a razão de ser e existir do utensílio nomeamos logo a sua utilidade, isto é, coisa dotada de serventia, cujo existir é marcado pela proximidade. No entanto, se nos distanciamos do utensílio -imaginemos como exemplo os talheres do nosso quadro apresentado de início, pendurados na parede, desgastados, como matéria desconformada; vazios de sua utilidade, porque caíram em desuso-, será que ainda assim, à distância, nunca chegaremos a saber o que é o "ser-utensílio do utensílio"?

Se é certo que o ser do utensílio reside em sua utilidade, como o que está próximo (quando do seu uso), também é verdade que a utilidade "reside na plenitude de um modo de ser essencial do utensílio" ${ }^{20}$, que se esvazia

\footnotetext{
${ }^{16}$ HEIDEGGER, "Der Ursprung des Kunstwerks" (GA 5), p. 7-68. (Cf. trad. ao português de Irene Borges-Duarte e Filipa Pedroso, "A origem da obra de arte". In: Caminhos de floresta. Lisboa: Fundação Gulbenkian, 2002). Também em "Das Ding" (GA 7), p. 165-188. (Cf. trad. ao português de Emmanuel Carneiro Leão, Gilvan Fogel, Marcia Sá Cavalcante Schuback, "A coisa". In: Ensaios e Conferências. Petrópolis: Vozes; Bragança Paulista: Editora Universitária São Francisco, 2012).

${ }^{17}$ Por exemplo, como delimitar um ente como coisa, frente ao outro ente que não é? $\mathrm{Ou}$, mais precisamente, quais destes entes consideramos coisas: o utensilio (um arado), o objeto (uma pedra), o ser vivo (uma pessoa)? Heidegger afirma que as interpretações da "coisidade" da coisa que se apresentam com mais frequência e soberania no decorrer da história do pensamento ocidental, podem ser resumidas em três 1) Como sujeito/predicado, isto, e a coisa como portadora de características, que se dá distante de nós. 2) Como reunião de sensações, isto é, como unidade de uma multiplicidade que se realiza no âmbito dos sentidos (calor, dureza, massa, etc), por isso, realiza-se muito próximo de nós. 3) Como matéria e forma, isto é, como "matéria conformada", que é produto de um fazer ou obrar (HEIDEGGER, "Der Ursprung des Kunstwerks" (GA 5), p. 12ss.).

${ }^{18}$ HEIDEGGER, “Der Ursprung des Kunstwerks" (GA 5), p. 18.

${ }^{19}$ HEIDEGGER, “Der Ursprung des Kunstwerks" (GA 5), p. 21.

${ }^{20}$ HEIDEGGER, “Der Ursprung des Kunstwerks" (GA 5), p. 23.
} 
e se rebaixa até se converter em uma "mera coisa", quando do seu desuso. E Heidegger acrescenta: "Porém, esta desaparição, da qual as coisas de uso devem sua aborrecida e insolente vulgaridade, é só um testemunho a mais da essência originária do ser-utensílio" ${ }^{21}$, cuja proximidade (identidade) reside naquilo que não necessariamente está próximo de nós. Ou seja, a colher vazia (em desuso) não deixa de ser coisa. Logo, o seu caráter de coisa permanece mesmo em seu desuso. Isso indica que a identificação da coisa vai muito além do mero sentido de seu uso. Quando as coisas estão despojadas de seu caráter de utensílio, elas seguem sendo coisas. Aí reside a coisidade da coisa, que vai muito além da sua utilidade imediata e instrumental, ou da mera relação entre matéria e forma.

Em suma, o ser-utensílio do ente, que ocupa um lugar privilegiado na interpretação do ente na atualidade, determina que o valor e o fim do ente não se satisfazem no ente em si mesmo, mas na exterioridade de sua aplicação, isto é, quando da sua condição tão somente de uso. Por isso que, com frequência, adequamos igualmente as coisas da natureza com as coisas de uso, alerta Heidegger. Logo, a própria categoria do servir para tende a objetificar a coisa em si, enquadrando-a no que é eficaz, essencializando a coisa no âmbito do seu uso. O útil é, então, um modo de ser como disposição que se realiza no âmbito da produção material, mas que se encerra exclusivamente no âmbito do utensílio. Assim, o útil do ente sempre se apresenta próximo à representação humana, na medida em que é nossa própria criação: o que é produzido com a finalidade da serventia.

O mesmo ocorre quando pensamos sobre o agir, posto que, logo o associamos à questão da utilidade como sinônimo de produzir um efeito, uma ação prática ${ }^{22}$. Entretanto, Heidegger adverte: "a essência do agir é consumar. Consumar significa desdobrar alguma coisa até à plenitude de sua essência; levá-la à plenitude, producere. Por isso, apenas pode ser consumado, em sentido próprio, aquilo que já é. O que, todavia, "é", antes de tudo, é o ser" ${ }^{23}$. Nessa perspectiva podemos, então, inferir que a essência do agir vai muito além desse sentido meramente utilitarista. Logo, pensar desde a categoria da essência do ser não é simplesmente pensar desde a categoria do útil.

Sobre este outro modo de pensar, ainda haveremos de tratar mais adiante. Por enquanto, ainda nos resta analisar com mais cuidado o sentido do útil, posto que esse modo de perceber as coisas e considerá-las úteis apenas quando representam um servir para (um fim utilitário que se realiza na ação prática), está atrelado a um modo de pensar que se reflete com toda claridade na era técnica em que vivemos e denuncia a nossa condição de

\footnotetext{
${ }^{21}$ HEIDEGGER, "Der Ursprung des Kunstwerks" (GA 5), p. 24.

${ }^{22}$ HEIDEGGER, "Brief über den Humanismus" (GA 9), p. 313, 353.

${ }^{23}$ HEIDEGGER, "Brief über den Humanismus" (GA 9), p. 313.
} 
como nos relacionamos com e no mundo. Heidegger nomeia este modo de pensar de calculador.

O pensar calculador [das rechnende Denken] indica aquilo que planifica, calcula e projeta a ação mediante o eficiente e o útil. Porém, o pensamento que calcula "não é um pensamento que medita, não é um pensamento que reflete sobre o sentido que reina em tudo o que existe"24. Aqui já se pode notar a semelhança do pensar calculador com o sentido atual do útil o qual já nos referimos. Pois, enquanto o útil se prende ao ente enquanto utensílio, o pensamento se prende ao ente como cálculo. O pensar calculador também é sinônimo de exatidão. Talvez por isso, quando levamos em consideração a concepção de que o pensamento exato é o pensamento mais rigoroso, ou que um pensamento mais sistemático é também mais rigoroso, acusa-se a poesia de ser sem rigor, de não servir de nada. Contudo, observa Heidegger, a aparente exatidão do pensar calculador, não significa rigorosidade, posto que se presta exclusivamente ao cálculo do ente e somente serve para tal:

Qualquer cálculo reduz todo o numerável ao enumerado, a fim de utilizá-lo para a próxima enumeração. $\mathrm{O}$ cálculo não admite outra coisa senão o enumerável. Cada coisa é apenas aquilo que se pode enumerar. O que a cada momento é enumerado assegura o progresso da enumeração. Essa utiliza progressivamente os números e é, em si mesma, um contínuo consumir-se ${ }^{25}$.

Operando sempre no terreno do calculável, do operativo, o pensar calculador parece não alcançar a proximidade das coisas. Ao contrário, viola tal proximidade, tornando as coisas meros objetos. O que vale é o resultado já delineado em seu cálculo. Assim, o pensar calculador pode passar a impressão de produtividade (ao realizar uma atividade tão prática e tão operativa, como é o caso da soma das partes, da divisão, da estimativa, da planificação, etc), mas esta é apenas a revelação da essência destruidora do cálculo ${ }^{26}$, ainda que disfarçada na aparente objetivação técnico-científica da natureza e na ideia de progresso. E por quê? Porque "o pensar calculador não é capaz de suspeitar que todo o calculável do cálculo já é, antes de suas somas e produtos calculados, um todo, cuja unidade, sem dúvida, pertence ao incalculável, que se subtrai a si e à sua estranheza das garras do cálculo"27, adverte Heidegger. Assim, o pensar que atua na esfera e na condição do cálculo, denuncia os limites do pragmatismo atual do pensamento, por meio do qual o próprio ato de pensar tem que se tornar utilitário. O que torna o pensamento refém de si mesmo, posto que o ato de pensar deve ser executado em favor da serventia, ou, como bem disse Leminski, em favor da "ditadura da utilidade".

\footnotetext{
${ }^{24}$ HEIDEGGER, “Gelassenheit” (GA 16), p. 520.

${ }^{25}$ HEIDEGGER, "Brief über den Humanismus" (GA 9), p. 308.

${ }^{26}$ HEIDEGGER, "Brief über den Humanismus" (GA 9), p. 309. Cf. também "Der Ursprung des Kunstwerks", p. 36.

${ }^{27}$ HEIDEGGER, “Brief über den Humanismus” (GA 9), p. 309.
} 


\subsection{A utilidade e a técnica moderna}

Se, segundo Heidegger, o pensar próprio da modernidade repousa no âmbito do cálculo, nele, as coisas se apresentam no mundo utilitariamente, sendo o "útil" um modo de ser como disposição, que se auto afirma no âmbito da produção material (poiésis), sobretudo. Daí que o pensar calculador se consagra com a técnica na modernidade, na medida em que a técnica passa a ser compreendida como fazer, isto é, desde o seu caráter instrumental e operativo. Assim, pensamos e estamos no mundo de forma tecnificada, restringindo a poiésis (o mundo da produção material) a um único sentido: o agir prático, eficiente e eficaz; que produz utilidades ${ }^{28}$.

Para melhor explicar como ou em que medida o significado de técnica moderna reflete a questão da utilidade, vale lembrar as concepções que, com frequência, diz-se da técnica ${ }^{29}$. A primeira ideia comumente designada de técnica consiste na visão antropológica e instrumental: a técnica é um fazer do homem, caracterizando-se como meio (instrumento) para um determinado fim (ação humana). A técnica é assim vista como um instrumento de manipulação do ser humano, sendo tal representação instrumental da técnica o reforço argumentativo da neutralidade do objeto técnico. Nesse sentido, Heidegger afirma: "A técnica passa por qualquer coisa que o homem manipula, da qual ele se serve na perspectiva de uma utilidade $^{\prime 30}$. Também a visão desenvolvimentista e evolucionista da técnica faz todo sentido nesta representação, posto que a história da técnica é sempre encarada como um processo evolutivo, que possibilita o desenvolvimento humano. Além disso, a técnica é habitualmente configurada pelo seu caráter de aplicação, ou seja, ela é um "conhecimento aplicado". Assim, a técnica moderna, enquanto mero instrumento, é considerada uma simples aplicação da ciência que se realiza no âmbito da produção em larga escala ou da técnica industrial, e que configura decisivamente o modelo civilizatório da modernidade.

No entanto, situar a pergunta e o sentido da técnica no domínio do meramente técnico, no âmbito do saber instrumental e aplicado, é reduzir o seu caráter

\footnotetext{
${ }^{28}$ Não por acaso, algumas teorias sobre a avaliação de tecnologias, inclusive provenientes de filósofos da tecnologia hoje em dia, consideram que são valores intrínsecos a elas, além da factibilidade, a eficiência e a eficácia. No primeiro caso, tem-se a possibilidade de aplicação de um sistema técnico a uma determinada cultura, ou sociedade. No segundo, trata-se de averiguar o grau de ajuste entre sua finalidade e seus resultados. E, no caso da eficácia, por conseguinte, trata-se de avaliar o alcance dos objetivos propostos em sua aplicabilidade. Uma exposição mais detalhada e análise crítica do assunto também se pode ver em: MIRANDA, A.L. ¿Una ética para la civilización tecnológica? Posibilidades y límites del principio de la responsabilidad de Hans Jonas. Alemanha/Espanha: Lap Lambert/EAE, 2012, p. 74ss.

${ }^{29} \mathrm{Cf}$. as referidas teses apresentadas por Heidegger sobre o conceito de técnica, em: Língua de tradição e língua técnica. Trad. Mário Botas. Passagens: Lisboa, 1995, p. 15-16.

${ }^{30}$ HEIDEGGER, Lingua de tradição e língua técnica. Trad. Mário Botas. Passagens: Lisboa, 1995, p. 18.
} 
mais essencial. Ou seja, ainda que seja correta, esta concepção de técnica não é de todo verdadeira, avalia Heidegger em A pergunta pela técnica. Para ele, a técnica em suas origens (ou a technè, em sentido grego), guardava profunda relação com a verdade como desvelamento do ser das coisas, através da produção material (poiésis). Logo, a técnica, mais que um sentido instrumental e utilitário, vinculava-se ao sentido filosófico e ontológico da poiésis (o mundo da produção material), como um desocultar o ser das coisas.

Ocorre que, à diferença da técnica dos antigos, o desocultar da técnica dos modernos consiste numa provocação: "uma exploração que impõe à natureza a pretensão de fornecer energia, capaz de, como tal, ser beneficiada e armazenada" ${ }^{31}$. Por isso, o homem da modernidade é um sujeito explorador, instrumentalista, operador e desafiador, que atua neste modo de descobrimento, próprio da técnica moderna, donde extrair, transformar, estocar, distribuir, são modos de sua realização.

Entrelaçada ao pensar calculador, a técnica moderna atua também na esfera da grande engrenagem do controle e da segurança. Logo, pensar é controlar a natureza e calcular, por meio dos artefatos técnicos, a nossa condição segura de estar e viver no mundo. Heidegger assim observa: "Por toda parte, assegura-se o controle. Pois, controle e segurança constituem as marcas fundamentais do descobrimento explorador" ${ }^{\prime \prime 2}$. O próprio uso da razão impele tudo ao cálculo e à planificação da natureza, considerada agora um grande fundo de reserva [Bestand] ${ }^{33}$ : matéria-prima aí, disponível ao ser humano. A poesia de Barros, neste sentido, é reveladora:

$\mathrm{O}$ rio que fazia a volta atrás da nossa casa era a imagem de um vidro mole que fazia volta atrás da casa.

Passou um homem depois e disse: Essa volta que o rio faz por trás da sua casa se chama enseada.

Não era mais a imagem de uma cobra de vidro que fazia uma volta atrás da casa.

Era uma enseada.

Acho que o nome empobreceu a imagem ${ }^{34}$.

${ }^{31}$ HEIDEGGER, “Die Frage nach der Technik" (GA 7), p. 15. (Cf. trad. ao português de Emmanuel Carneiro Leão, Gilvan Fogel, Marcia Sá Cavalcante Schuback, "A questão da técnica". In: Ensaios e Conferências. Petrópolis: Vozes; Bragança Paulista: Editora Universitária São Francisco, 2012).

${ }^{32}$ HEIDEGGER, “Die Frage nach der Technik” (GA 7), p. 17.

${ }^{33}$ Heidegger também se refere à calculabilidade [Berechenbarkeit], que transforma os entes em meras subsistências, disponível aí ao ser humano. Por isso, a natureza é vista com um grande fundo de reserva [Bestand]. Veja-se: Identität und Differenz (GA 11), p. 43. (Cf. trad. ao português de Ernildo Stein, "Identidade e diferença". In: Conferências e escritos filosóficos. São Paulo: Abril Cultural, 1989). Essa mesma ideia também aparece na conferência de Heidegger, "Die Frage nach der Technik" (GA 7) e em "Wozu Dichter?" (GA 5), p. 289. (Cf. trad. ao português de Bernhard Sylla e Vítor Moura, "Para que poetas". In: Caminhos de floresta. Lisboa: Fundação Gulbenkian, 2002).

${ }^{34}$ BARROS, Meu quintal é maior que o mundo. Rio de Janeiro: Objetiva, 2015, p. 85. 


\subsection{A utilidade e a linguagem}

Pelo pensar calculador, portanto, o ente é revelado como utensílio, o útil é o que serve para, e a técnica é a materialização deste modo de pensar que impele tudo ao cálculo e à planificação. E se a coisa é objetivada, como instrumentum o mesmo ocorre com a linguagem, que passa a ser compreendida como instrumento comunicativo. À linguagem lhe cabe, agora, uma função meramente instrumental e informacional. Seu sentido poético (imagético) e ontológico de outrora, de nada vale. Posto que, na era da técnica moderna, a linguagem não significa mais o "dizer", no sentido de mostrar, fazer ou escutar algo e fazer aparecer. No mundo tecnificado, cuja ação é o que produz resultado, a linguagem converteu-se em informação, que significa simplesmente "dar notícia de". Por isso, construímos máquinas de pensar e edificamos grandes centros de cálculos ${ }^{35}$.

Mas, a informação que "dá a notícia de", não somente "informa"; ela também "forma". Ou, melhor dizendo, "deforma", insinua Heidegger na Carta sobre o humanismo, quando diz que se trata da decadência da linguagem, abandonada "ao nosso querer e fazer a modo de instrumento de dominação sobre o ente" ${ }^{36}$. Como disse o poeta, "o nome empobreceu a imagem", porque o ente tem que aparecer (por meio da linguagem) sempre enredado na relação de causa e efeito. Daí que tem mais propriedade para tal a ciência: quanto mais exata for, maior credibilidade terá. Nisso se confirma o que Heidegger diz: "Não somos nós que possuímos a linguagem, é a linguagem que nos possui para o melhor e para o pior" ${ }^{\prime 37}$.

Do sentido reducionista dado agora à linguagem, que se contenta apenas em informar e notificar, parece desafiar a poesia de Manoel de Barros, tal como observa Tânia Lima: “O poeta coloca desconfiança na palavra e duvida da utilidade de expressão da mesma" ${ }^{38}$. A poesia de Manoel de Barros põe de manifesto, portanto, seu rechaço à linguagem como simples notificação do real ou como relação de causa e efeito. Descontente com apenas informar, o poeta procura uma linguagem (aparentemente) "deformada" e desconectada da realidade, porque, mais que notificar ou informar sobre o real, ao poeta lhe interessa versificar sobre suas "insignificâncias". Sua competência é a profundidade sobre o nada, como ele mesmo escreve:

\footnotetext{
${ }^{35}$ Heidegger diz: "Hoje em dia, a máquina do pensar calcula, em um segundo, milhares de relações. Apesar de sua utilidade, estão privadas de essência" (Identität und Differenz (GA 11), p. 50).

${ }^{36}$ HEIDEGGER, “Brief über den Humanismus" (GA 9), p. 318.

${ }^{37}$ HEIDEGGER, Hölderlins Hymne. "Germanien" und "Der Rhein" (GA 39), p. 24. (Cf. trad. ao português de Lumir Nahodil, Hinos de Hölderlin. Lisboa: Instituto Piaget, 2004).

${ }^{38}$ LIMA, T. Diário de flores ou lamento de um blue. Natal: Lucgraf, 2010, p. 58.
} 
POEMA

A poesia está guardada nas palavras - é tudo que eu sei.

Meu fado é o de não saber quase tudo.

Sobre o nada eu tenho profundidades.

Não tenho conexões com a realidade.

Poderoso para mim não é aquele que descobre ouro.

Pra mim poderoso é aquele que descobre as

insignificâncias (do mundo e as nossas).

Por essa pequena sentença me elogiaram de imbecil.

Fiquei emocionado e chorei.

Sou fraco para elogio ${ }^{39}$.

Assim, tal como parece inclinar a posição heideggeriana, Manoel de Barros também se distância em sua poesia do sentido frequente atribuído ao que é útil, subvertendo o seu significado e atrelando-o ao sentido de inútil, daquilo que costuma ser insignificante, do qual trataremos a seguir.

\section{O inútil}

\subsection{Pensando o inútil}

Enquanto o sentido do útil, habitualmente, é entendido desde o que serve para, o sentido do inútil, ao contrário, transita entre aquelas coisas que não servem para. O não servir é utilizado como sinônimo de desprezível, improdutivo; que não é aplicável em sentido utilitário, desnecessário. E o ímpeto de encontrar necessidades imediatas em tudo é tanto hoje em dia, que somos impelidos a justificar a utilidade das coisas até mesmo onde não há a menor chance de encontrá-la. Em O indispensável in-útil, Leminski explica esta condição, presente, por exemplo, na arte:

As pessoas sem imaginação estão sempre querendo que a arte sirva para alguma coisa. Servir. Prestar. O serviço militar. Dar lucro. Não enxergam que a arte (a poesia é arte) é a única chance que o homem tem de vivenciar a experiência de um mundo da liberdade, além da necessidade. As utopias, afinal de contas, são, sobretudo, obras de arte. E obras de arte são rebeldias (...) com o radical incômodo de uma coisa in-útil num mundo onde tudo tem que dar um lucro e ter um por quê. Para que por quê? ${ }^{40}$

Nos moldes da serventia e do utilitário, todos os porquês já estão calculadamente definidos e delimitados. E se não há um porquê explicativo para

${ }^{39}$ BARROS, Tratado geral das grandezas do infimo. Rio de Janeiro: Record, 2001, p. 125.

${ }^{40}$ LEMINSKI, Ensaios e anseios crípticos. Campinas: Editora da Unicamp, 2012, p. 78-79. 
cada coisa, não há serventia. Talvez, por isso, sem temor e com profunda ironia Manoel de Barros anuncia: "o poema é antes de tudo um inutensílio" $^{41}$. Contrariando essa lógica que tem em vista sempre um produto utilitário, o poeta impregna sua poesia de vários "in" e "des", presentes em seus versos: desúteis, desobjetos, descomportamento, desimportantes, inúteis. Assim, "o inútil torna-se totalmente útil", posto que o "poeta da inutilidade esvazia o conceito de utilidade de qualquer referência de uso, conseguindo assim transformar o utilitarismo em um arsenal de coisas inúteis ${ }^{42}$. Nada mais apropriado que testemunhar o esvaziamento da utilidade nos próprios versos de Manuel de Barros:

\section{O CATADOR:}

Um homem catava pregos no chão.

Sempre os encontrava deitados de comprido, ou de lado, ou de joelhos no chão.

Nunca de ponta.

Assim eles não furam mais -o homem pensava.

Eles não exercem mais a função de pregar.

São patrimônios inúteis da humanidade.

Ganharam o privilégio do abandono.

O homem passava o dia inteiro nessa função de catar pregos enferrujados.

Acho que essa tarefa lhe dava algum estado.

Estado de pessoas que se enfeitam de trapos.

Catar coisas inúteis garante a soberania do Ser.

Garante a soberania de Ser mais do que $\mathrm{Ter}^{43}$.

Em Heidegger também encontramos algo semelhante. O útil é o que conduz o homem a descobrir a sua essência, cuja busca reside na clareira do ser. E isso é todo o contrário do que é o útil para o mundo tecnificado atual. Ou seja, para o homem técnico isso seria o inútil, o que deve ser abandonado. Daí a máxima heideggeriana: "O mais útil é o inútil"44. Ocorre que para o homem moderno (o homo faber) $)^{45}$-acostumado a compreender "o útil" vinculado sempre e diretamente aos fins técnicos, ou seja, aquilo que causa algum efeito prático que ele mesmo produz-, "experienciar o inútil" é o mais difícil. E Heidegger indica: Deve-se ver o útil no sentido daquilo que cura, isto é, como aquilo que conduz o homem a si mesmo ${ }^{46}$. O sentido de

\footnotetext{
${ }^{41}$ BARROS, Meu quintal é maior que o mundo. Rio de Janeiro: Objetiva, 2015, p. 55.

${ }^{42}$ LIMA, Diário de flores ou lamento de um blue. Natal: Lucgraf, 2010, p. 70.

${ }^{43}$ BARROS, Poesia completa. São Paulo: Leya, 2010, p. 410.

${ }^{44}$ HEIDEGGER, Zolikoner Seminare (GA 89), p. 204, grifo nosso. (Cf. trad. ao português de Gabriella Arnhold e Maria de Fátima de Almeida Prado, Seminários de Zollikon. Petrópolis: Vozes; Bragança Paulista: Editora Universitária São Francisco, 2009).

${ }^{45}$ Sobre o reducionismo do conceito de homo faber, veja-se a crítica de Heidegger em Seminários de Bremen - Das Ge-Stell (GA 79), p. 37ss.

${ }^{46}$ HEIDEGGER, Zolikoner Seminare (GA 89), p. 204.
} 
"curar" alberga o âmbito do cuidar, porque, para Heidegger, o homem é o pastor do ser. Aquele que cuida e vigia. Logo, o pensamento, como guardião do ser, em muito difere do mero ato de produzir efeitos, posto que se trata, antes de tudo, do cuidado com o ser, aquele que é o mais universal e vazio de todos os conceitos e que se alcança pelo pensar meditativo.

\subsection{O pensar meditativo e a poética do inútil}

Como já fora dito na parte introdutória, diferentemente do pensar calculador, o pensamento meditativo não repousa no cálculo, mas na meditação que dá o que pensar. Mas, o que quer dizer algo que dá o que pensar? Segundo Heidegger, "Vivemos numa época estranha, singular e inquietante. Quanto mais desenfreadamente aumenta a quantidade de informação, mais decididamente se amplia o ofuscamento e a cegueira para os fenômenos" ${ }^{47}$. E como informação, por si só, não é sinônimo de conhecimento, somos ludibriados (e, ao mesmo tempo, compensados) pelo aumento desmedido da informação, sem que isso nos leve à capacidade de discernir. Assim é que o pensamento moderno se transforma num calcular que se exige e se expande cada vez mais, porém, sem consciência.

Portanto, é a cegueira do modo de pensar atual que dá o que pensar. Dá o que pensar, sobretudo, porque este mesmo pensamento, paradoxalmente, tem se proclamado em nossa época como esclarecido e iluminado e se vangloria dos feitos e progressos da ciência e da tecnologia ${ }^{48}$. E isso ocorre não somente no âmbito da ciência e da técnica, mas também da própria filosofia. É nessa perspectiva que Heidegger atenta para a diferença entre o pensamento e a filosofia: o filosofar não garante de igual modo o pensar. Ou seja, o fato de se ocupar com a filosofia não nos garante ainda uma disponibilidade para o pensamento. "Para que um tal intento seja bem-sucedido, é preciso que nos disponhamos a aprender a pensar". E "o preocupante do nosso tempo -um tempo que dá o que pensar- é que, todavia, não pensamos" ${ }^{49}$ sobre o que urge ser pensado.

O que urge ser pensado é exatamente como transpor a barreira do mero calculado, daquilo que é a mera representação do real objetivado. Por isso, Heidegger afirma categoricamente que a ciência não pensa ${ }^{50}$. A ciência não

\footnotetext{
${ }^{47}$ HEIDEGGER, Zolikoner Seminare (GA 89), p. 96.

${ }^{48}$ A propósito, veja-se também a crítica dos frankfurtinianos (Horkheimer, Marcuse, Habermas). ${ }^{49}$ HEIDEGGER, "Was heißt Denken?" (GA 7), p. 129,13. (Cf. trad. ao português de Emmanuel Carneiro Leão, Gilvan Fogel, Marcia Sá Cavalcante Schuback. "O que quer dizer pensar?". In: Ensaios e Conferências. Petrópolis: Vozes; Bragança Paulista: Editora Universitária São Francisco, 2012).

${ }^{50}$ HEIDEGGER, “Was heißt Denken?" (GA 7), p. 129; "Wissenschaft und Besinnung" (GA 7), p. 37ss. (Cf. trad. ao português de Emmanuel Carneiro Leão, Gilvan Fogel, Marcia Sá Cavalcante Schuback, "Ciência e pensamento do sentido". In: Ensaios e Conferências. Tradução de Petrópolis: Vozes; Bragança Paulista: Editora Universitária São Francisco, 2012).
} 
pode pensar porque não deixa aparecer o presente, ou seja, o pensar da ciência somente re-presenta, já que somente articula objetos em sua objetualidade, seja como medida ou cálculo. De forma poetizada, o mesmo diz Manoel de Barros:

A ciência pode classificar e nomear os órgãos de um sabiá mas não pode medir seus encantos.

A ciência não pode calcular quantos cavalos de força existem nos encantos de um sabiá.

Quem acumula muita informação perde o condão de adivinhar: divinare.

Os sabiás divinam ${ }^{51}$.

Dessa forma, a ciência não pensa porque se transfigura na objetividade e no domínio dos objetos, acumulados em informação (tal como diz o poeta). E, na medida em que se aproxima de uma interpretação técnica do pensar, afasta-se da própria essência do pensamento (tal como diz o filósofo). Em contrapartida, o pensar meditativo é impulsionado na direção de buscar, antes de tudo, uma reflexão do próprio modo de pensar: o pensar que se revela na contemplação das coisas, na guarda do ser. O pensar meditativo, pois, trata da relação essencial, que diz respeito às coisas não apenas como utensílio, como mera subsistência [Bestände] e serventia, mas como substância [Gegenstände] ${ }^{52}$ : algo que está aí diante, num cara a cara, que abre espaço à prática meditativa e poética. Isso quer dizer que é preciso ultrapassar a mera relação de sujeito e objeto no processo de conhecimento, se queremos alcançar tal forma de pensamento.

A esta altura já vamos nos aproximando de uma das questões que norteiam nosso caminho, mas que ficou lá atrás, ainda quando iniciávamos este percurso: Então, é possível a técnica abrigar o pensar meditativo? Ou ainda, pode a técnica em sua essência abrigar o sentido do inútil? Numa tentativa de se aproximar ainda da pergunta (mais que da resposta, por enquanto), atentemo-nos à poesia de Manoel de Barros, encontrada na segunda parte do Livro sobre nada, que nos situa diante da imagem de um prego, mas não pensado apenas desde a sua função utilitária de pregar. O que está mais além da mera utilidade deste utensílio (tal como diria Heidegger), é contemplado pelo poeta, assumindo que ele poderia ser, inclusive, um anúncio de solidão:

Vi um prego do Século XIII, enterrado até o meio numa parede de $3 \times 4$, branca, na XXIII Bienal de Artes

Plásticas de São Paulo, em 1994.

Meditei um pouco sobre o prego.

${ }^{51}$ BARROS, Livro sobre nada, Rio de Janeiro: Record, 1996, p. 53.

${ }^{52}$ HEIDEGGER, "Vier Seminare" (Le Thor/1969) GA 15, p. 367-368. 
$\mathrm{O}$ que restou por decidir foi: se o objeto enferrujado

seria mesmo do Século XIII ou do XII?

Era um prego sozinho e indiscutível.

Podia ser um anúncio de solidão.

Prego é uma coisa indiscutível ${ }^{53}$.

Retomamos, agora, outra consideração importante feita por Heidegger à qual fizemos alusão, quando tratamos do sentido da técnica. Para os antigos, a técnica é, antes de tudo, um modo de fazer o ser chegar à presença pela produção material (poiésis). Ou seja, mais do que instrumentum, a técnica é uma forma de verdade, cujo desocultamento do ser das coisas se dá através da produção material. Recordemos que essa é a diferença elementar que marca o modo de conceber a técnica entre os antigos e os modernos, ensina Heidegger em seu perguntar pela técnica ${ }^{54}$. Outra diferença, e não menos significativa, que marca o modo de conceber a técnica entre estes dois mundos (dos Antigos e dos Modernos) é que esse desocultar, através da technè, em sentido grego, não se dá de forma provocativa, como é vista na técnica em sentido moderno -tal como já nos referimos a ela anteriormente-, mas de uma forma que se preserva o mistério e a essência das coisas. Semelhante ao modo como Manoel narra o tempo do "plantio" dos versos poéticos, onde o desvelamento do poema a partir da linguagem preserva o mistério e o tempo da construção-poética. Por isso, ele compara seu trabalho ao do roceiro, tal como já vimos ao descrever o contexto de seu pensamento: "Abro a terra e boto as sementes/ Deixo as sementes para a chuva enternecer/ Dou um tempo (...) e deixo o texto germinar sobre o branco do papel" ${ }^{\prime 5}$.

As "despalavras" de Manoel e a "tarefa do pensar" de Heidegger apontam para essa possibilidade: que o fazer, o mundo da produção material (seja a técnica ou a arte) pode ir além da mera utilidade. Para o filósofo, a técnica assume essencialmente o valor daquilo que, mais que ser útil, antes de tudo, é uma forma de verdade que se revela pela poiésis. Para o poeta, as coisas valem por si mesmas, mesmo depois de abandonadas à condição de inutilidades. Assim justifica Manoel de Barros:

Prefiro as máquinas que servem para não funcionar: quando cheias de areia de formiga e musgo - elas podem um dia milagrar de flores.

(Os objetos sem função têm muito apego pelo abandono.)

Também as latrinas desprezadas que servem para ter grilos dentro - elas podem um dia milagrar violetas.

(Eu sou beato em violetas. $)^{56}$.

${ }^{53}$ BARROS, Poesia completa. São Paulo: Leya, 2010, p. 342.

${ }^{54}$ HEIDEGGER, “Die Frage nach der Technik" (GA 7), p. 5-36.

${ }^{55}$ BARROS, Poesia completa. São Paulo: Leya, 2010, p. 380-381.

${ }^{56}$ BARROS, Livro sobre nada, Rio de Janeiro: Record, 1996, p. 57. 
Se, antes, o útil se materializava no utensílio, cujo valor repousa no seu resultado e na sua finalidade eficazmente calculada, agora o útil repousa na ação desprovida de resultado; livre das garras do calculado e do planificado, que não precisa prestar contas da sua eficácia ${ }^{57}$. Neste sentido, técnica e arte, ao contrário do que se pensa hoje em dia, possuem uma profunda e estreita relação. Daí que para os gregos, ambas pertencem ao mundo da produção material. Logo, poiésis e poética não se afastam, mas se aproximam. São modos de deixar aparecer o ser que vão muito além das virtudes do utilitário simplesmente. Novamente a poesia de Manoel de Barros nos traz luz, ao anunciar as virtudes do inútil, versificado através do doido de Rabelais:

\section{RABELAIS}

Por volta de 1532 andava pelas ruas de Paris

o doido de Rabelais.

O doido apregoava pregos enferrujados.

Ele sabia o valor do que não presta.

Rabelais chegaria a imaginar assim:

Quem atinge o valor do que não presta é, no mínimo,

Um sábio ou um poeta.

É no mínimo alguém que saiba dar cintilância aos seres apagados.

$\mathrm{Ou}$ alguém que possa frequentar o futuro das palavras.

Vendo aquele maluco de rua a apregoar pregos enferrujados

$\mathrm{O}$ nosso pensador imaginou que talvez quisesse aquele homem

Anunciar as virtudes do inútil. (Rabelais já havia afirmado antesmente que poesia é

uma virtude do inútil) $)^{58}$.

A saída anunciada pelo poeta desde a poética do inútil não está somente em se distanciar do sentido da utilidade, consolidada pela visão utilitarista tão em moda hoje em dia. É preciso, ainda, recuperar o sentido da inutilidade, levando em consideração o valor daquele que sabe "dar cintilância ao seres apagados" e que parece iluminá-los, como uma clareira em direção ao ser. Diante dessa proposta -entendendo-se a utilidade desde a sua essência, que torna o inútil vigente-, haveríamos de repensar, então, se, em verdade, o verso poético tem menos utilidade do que uma usina atômica, ou se a hidrelétrica é mais útil que o rio, ou se o pássaro é menos útil do que o avião, ou se o pensar que medita tem menos importância que o que calcula. No livro Concerto a céu aberto para solos de ave, como um ensaio de resposta, o poeta insinua: "Eis o aranquã - um pássaro sem indústria/ $\mathrm{O}$ passado obscuro dele é um rio/ Sua voz tem um som vegetal" ${ }^{15}$. O significativo aqui é que a ressignificação do pensar,

${ }^{57}$ LOPARIC, Z. "Ética e finitude". In: A crise do pensamento. Benedito Nunes (Ed.). Belém: Editora da UFPa, 1994, p. 77.

${ }^{58}$ BARROS, Poesia completa. São Paulo: Leya, 2010, p. 387.

${ }^{59}$ BARROS, Poesia completa. São Paulo: Leya, 2010, p. 277. 
implica também na ressignificação da nossa condição de estar no mundo (que, por sua vez, diga-se de passagem, também se reflete na poiésis, no modo como nos relacionamos com o mundo), onde a natureza deixa de ser compreendida como matéria-prima, como um fundo de reserva, e passa a ser vista desde a poética, como matéria de poesia, (re)vista e (trans)vista pelos versos do inútil. Por isso, diante da sua versificação antirracional e ligada às coisas desúteis, o poeta conclui:

Tudo aquilo que a nossa civilização rejeita, pisa e mija em cima, serve para poesia

(...)

As coisas sem importância são bens de poesia ${ }^{60}$.

\section{Habitando as coisas infimas: 0 passo atrás}

Se "as coisas sem importância são bens da poesia" (como diz o poeta), e se a essência da técnica repousa numa forma de verdade que se realiza através da produção material, e que, portanto, vai muito além da mera produção de utensílios (como diz o filósofo) haveremos, então, de repensar a condição atual em que nos encontramos. E quando Heidegger anuncia que a era é técnica não somente porque vivemos sob a égide dos aparatos técnicos, mas, e sobretudo, porque o modo de pensar também se tornou técnico, parece que aqui está o fio condutor por meio do qual justificamos essa condição. O passo atrás [Schritt zurück], situa-se, pois, nesse contexto ${ }^{61}$.

${ }^{60}$ BARROS, Meu quintal é maior que o mundo. Rio de Janeiro: Objetiva, 2015, p. 46-47.

${ }^{61}$ Muito embora aqui tomemos de empréstimo o sentido do passo atrás sugerido por HEIDEGGER, sobretudo, em seu escrito $A$ coisa [Das Ding] (GA 7), vale dizer que também em Identidade e diferença [Identität und Differenz] (GA 11) Heidegger esclarece que, do ponto de vista conceitual e metodológico, o passo atrás [Schritt zurück] não quer dizer dar um passo isolado do pensar e nada tem a ver com a ideia de voltar atrás, ao começo. Ainda que o passo atrás esteja vinculado ao largo caminho da história da filosofia ocidental, nesse contexto, ele indica o caminho que possa conduzir um certo modo de pensar distinto do que até agora tem sido pensado no decorrer da história (GA 11, p. 59). Portanto, o sentido de passo atrás sugerido por Heidegger deve ser compreendido dentro de sua proposta de fazer história da filosofia, cujo objeto central é o ser, postulado com a pergunta: de que modo o ser tem se apresentado nos distintos momentos da história ocidental? E de que modo o ser se apresenta na atualidade, por meio da era técnica? Desde esta pergunta se situa o passo atrás sugerido por Heidegger, como superação da metafísica que, na atualidade da era técnica, abdicou-se do ser para simplesmente descrever o ente, isto é, abdicou-se do ontológico para situar-se no âmbito meramente do ôntico. Desde esta diferença que marca o ser e o ente, Heidegger assim postula: “o passo atrás vai desde o impensado, desde a diferença enquanto tal, até o que está por pensar: o esquecimento da diferença. $O$ esquecimento que há que pensar é esse velamento Dhqh (encobrimento) a partir da diferença enquanto tal. Velamento que foi subtraído desde o princípio" (GA 11, p. 59). E prossegue: "A diferença de ente e ser é o âmbito dentro do qual a metafísica, o pensamento ocidental na totalidade de sua essência, 
Na atualidade da era da técnica, em que o ser se apresenta de modo tecnificado, tal tarefa consiste em postular um pensamento que não apenas representa o ser no plano do ôntico, dos existentes -como objetos postos para a dominação do homem-, mas que, antes de tudo, medita; que reflete o próprio sentido no plano ontológico. $\mathrm{O}$ passo atrás consiste, pois, em refundar o sentido do ontológico. Nisso está implicado, sobretudo, a tarefa de pensar a essência da técnica moderna como forma de metafísica. Algo que, todavia, está por pensar, observa Heidegger. O passo atrás consiste, ainda, na vigilância do pensar. Essa necessidade de vigília, Heidegger assim a explica, quando procura situar o sentido da essência da coisa como o aproximar-se do mundo:

Quando e como as coisas chegam, como coisas? Não chegam através dos feitos e dos artefatos do homem, mas também não chegam, sem a vigilância dos mortais. O primeiro passo na direção dessa vigília é o passo atrás, o passo que passa de um pensamento, apenas, representativo, isto é, explicativo, para o pensamento meditativo, que pensa (rememora) o sentido ${ }^{62}$.

Porém, de que forma podemos garantir o caminhar que leve em conta o passo atrás, sem que caiamos, ao fim e ao cabo, na própria engrenagem do pensar instrumental e calculador? De que modo o nosso agir pode transcender uma mera mudança de método, diante do pensar representativo e utilitarista? O rumo da resposta parece nos conduzir ao modo de experienciar a proximidade das coisas. Para tanto, é necessário dar o passo atrás para perceber que outro modo há de se compreender o ser que não calculadamente, onde as coisas não sejam apenas o outro lado objetificante em sua representação. Se queremos ir mais além da mera relação sujeito e objeto, é necessário um habitar o mundo, mais que simplesmente manipulá-lo. A propósito, Merleau-Ponty diz, em seu ensaio sobre $O$ olho e o espírito, que a ciência se resigna em habitar as coisas, contentando-se somente em manipulá-las. Daí que pensar "é ensaiar, operar, transformar, sob a única reserva de um controle experimental". E conclui: "Dizer que o mundo é por definição nominal, o objeto $X$ das nossas operações, é levar ao absoluto a situação de conhecimento do cientista, como se tudo o que foi ou é nunca houvesse sido senão para entrar no laboratório"63.

Superar o pensar do controle experimental, portanto, exige o passo atrás, onde, pelo habitar poético (o agir poético) seja possível ouvir o apelo do ser, sem que, para isso, seja necessária sua violação, e sim resguardando essa

pode ser o que é. Por isso, o passo atrás vai desde a metafísica até a essência da metafísica" (GA 11, p. 60). Logo, “o passo atrás desde a metafísica à essência da metafísica é, visto desde a atualidade e a partir da ideia que temos formado dela, o passo que vai desde a tecnologia e a descrição tecnológica da época, até essa essência da técnica moderna que ainda está por pensar" (GA 11, p. 61).

${ }^{62}$ HEIDEGGER, “Das Ding” (GA 7), p. 183.

${ }^{63}$ MERLEAU-PONTY, M. O olho e o espírito. Trad. Paulo Neves e Maria Ermantina Galvão Gomes Pereira. São Paulo: Cosac \& Naify, 2004, p. 13-14. 
distância que aproxima. Enquanto a ciência e a técnica violam essa proximidade dentro do seu modo de representação do real e, com isso, distanciam-se ainda mais da essência das coisas, o olhar poético, por sua vez, preservando o mistério das coisas (sem objetivá-las), torna-as mais próximas.

Se a pergunta sobre como transcender ou superar a barreira e a cegueira do pensar calculador e do agir utilitarista, até aqui, tem nos conduzido em direção ao passo atrás heideggeriano e seu pensar meditativo (que rememora), a partir de agora ela também nos conduzirá até o habitar as coisas ínfimas de Manoel de Barros. E, para introduzir o poeta neste estado da coisa, nada mais apropriado que seus próprios versos, transcritos no Livro de pré-coisas, cujo título, por si só, já dá o que pensar. Nele, o poeta parece indicar o caminho: "Sei de muitas coisas das cousas / Hai muitas importâncias sem ciência" ${ }^{64}$. Daí nossa desconfiança: E será que essas "importâncias sem ciência", esse estado de "pré-coisas" visualizado pelo poeta não quer indicar exatamente o "passo atrás" visualizado pelo pensador? Na continuidade de seu poema, Barros insinua que o que sabe vem do rememorar o sentido, quando diz: "Sei que os rios influem nas plumagens das aves / E que as casas com rio no fundo adquirem gosto de infância". No Tratado geral das grandezas do infimo, novamente identificamos a proximidade entre o filósofo e o poeta, quando Barros fala do grandioso de tudo aquilo que parece insignificante, mas que lhe importa:

\section{(...).}

O homem que deixou a vida por se sentir um esgoto -

Acho mais importante do que uma Usina Nuclear.

Aliás, o cu de uma formiga é também muito mais importante do que uma Usina Nuclear.

As coisas que não têm dimensões são muito importantes.

Assim, o pássaro tu-you-you é mais importante por seus

pronomes do que por seu tamanho de crescer.

É no ínfimo que eu vejo a exuberância ${ }^{65}$.

O pensar poético pois, abre espaço à percepção de outro mundo (poiético), ou da, digamos assim, outra poiésis do mundo. Novamente aqui, nos deparamos com nosso fio condutor, cujo pensar poético encaminha o homem ao encontro de sua essência e ao reencontro com o seu habitar, tal como diz Heidegger, parafraseando o poeta Hölderlin, "poeticamente o homem habita" a terra ${ }^{66}$. Já nos referimos ao habitar, quando tratamos

${ }^{64}$ BARROS, Poesia completa. São Paulo: Leya, 2010, p. 225.

${ }^{65}$ BARROS, Poesia completa. São Paulo: Leya, 2010, p. 341.

${ }^{66}$ Trata-se de um dos escritos de Heidegger sobre o sentido da ação. Assim ele esclarece: “... poeticamente o homem habita..., melhor diz o seguinte: o poetizar é o que antes de mais nada deixa ao habitar ser um habitar. Poetizar é propriamente deixar habitar. (...). Poetizar como deixar habitar é um construir" (Cf. "...dichterisch wohnet der Mensch..." (GA 7), p. 193). (Cf. trad. ao português de Emmanuel Carneiro Leão, Gilvan Fogel, Marcia Sá Cavalcante Schuback, “...Poeticamente o homem habita...". In: Ensaios e Conferências. Petrópolis: Vozes; Bragança Paulista: Editora Universitária São Francisco, 2012). 
anteriormente da poiésis e da poética do inútil, mas vale insistir um pouco mais em seu sentido. Sobretudo, porque, agora, quiçá seja possível também se aproximar da resposta de se pode a técnica abrigar o pensar meditativo.

No contexto da nossa proposição, habitar poeticamente o mundo tem o sentido do construir poético. Trata-se sim de poiésis. Mas que está muito mais aparentada com a poética do mundo (arte), do que com a técnica em sentido moderno. Trata-se de um agir que não está condicionado ao resultado da serventia, da produção do útil, do utensílio. E Heidegger esclarece: "Por isso, o poetizar não é de modo algum construir, no sentido de levantar edifício e equipa-los" ${ }^{\prime 67}$. Em sentido ético e ontológico é um permanecer que, mais que dominar, significa um "usufruir da terra como terra". Diz sobre um sentido de ação, portanto, que contrasta com a "diretriz calculadora, utilitarista da civilização técnica dominante da época" ${ }^{68}$. Desde a perspectiva do poeta Manoel de Barros, o habitar ocorre, na medida em que as coisas não estão postas desde uma realidade que pode ser medida, mas desde a sua insignificância que pode ser sentida, assim como ele mesmo diz: "é no ínfimo que eu vejo a exuberância". Ou como o andarilho Bernardo da Mata que, insistindo nas "origens do Ser", mergulhava nas coisas desimportantes em seu fazer e atingia as suas inexistências, como: "ouvir as vozes do chão", a "fala das águas", o "silêncio das pedras", o "crescimento das árvores",

(...)

E as origens do Ser. Pois Pois.

Bernardo da Mata nunca fez outra coisa

Que ouvir as vozes do chão

Que ver o silêncio das formas

E o formato dos cantos. Pois Pois.

Passei muitos anos a rabiscar, neste caderno, os

escutamentos de Bernardo.

Ele via e ouvia inexistências.

$\mathrm{Eu}$ penso agora que esse Bernardo tem cacoete para poeta $^{69}$.

Se voltamos ao pensamento de Heidegger, também aí vemos o intento de voltar à proximidade do ser. Ele mesmo dizia que pensar (meditativamente) é ouvir a voz do ser $^{70}$. E acrescenta: "Caso o homem encontre, alguma

\footnotetext{
${ }^{67}$ HEIDEGGER, “...dichterisch wohnet der Mensch...” (GA 7), p. 206. A propósito ver também seu escrito "Bauen Wohnen Denken" (GA 7), p. 145-164. (Cf. trad. ao português de Emmanuel Carneiro Leão, Gilvan Fogel, Marcia Sá Cavalcante Schuback, “Construir, habitar, pensar". In: Ensaios e Conferências. Petrópolis: Vozes; Bragança Paulista: Editora Universitária São Francisco, 2012).

${ }^{68}$ Ver o interessante artigo de NUNES, B. “Heidegger e a poesia". In: Natureza Humana, 2(1), São Paulo, 2000, p. 117.

${ }^{69}$ BARROS, Tratado geral das grandezas do ínfimo. Rio de Janeiro: Record, 2001, p. 128.

${ }^{70}$ HEIDEGGER, "Brief über den Humanismus" (GA 9), p. 310-311.
} 
vez, o caminho para a proximidade do ser, então deve antes aprender a existir no inefável (...)" $)^{\prime \prime 1}$. Dito isso, somos inclinados a crer que Manoel de Barros é um destes poetas que abrem caminho para a proximidade do ser e que deixam transparecer, pela linguagem, a manifestação do ente enquanto ente ${ }^{72}$. Sua poesia recorre ao apelo constante de ouvir a voz do ser, fazendo da linguagem sua morada. Como explica o próprio Heidegger: "Os pensadores e poetas são os guardiães dessa morada. Sua guarda consiste em levar a cabo a manifestação do ser, na medida em que, mediante seus dizeres, eles a levam à linguagem e ali mantém sua custódia"73.

Em suma, as coisas ínfimas em Manoel de Barros parecem instaurar, em seu habitar poético, a questão do passo atrás proposta por Heidegger. De um habitar que consiste em "aprender a existir no inefável"; que leva em consideração o existir poético como o que dá o que pensar, baseando-se no agir que, ultrapassando o útil que se esvai no utensílio, eleva-se no sentido da consumação: do chegar à plenitude da essência das coisas, em direção ao ser. Como no Retrato quase apagado em que se pode ver perfeitamente nada:

Não tenho bens de acontecimentos.

$\mathrm{O}$ que não sei fazer desconto nas palavras.

Entesouro frases. Por exemplo:

- Imagens são palavras que nos faltaram.

- Poesia é a ocupação da palavra pela Imagem.

- Poesia é a ocupação da Imagem pelo Ser.

Ai frases de pensar!

Pensar é uma pedreira. Estou sendo.

Me acho em petição de lata (frase encontrada no lixo). Concluindo: há pessoas que se compõem de atos, ruídos,

Retratos.

Outras de palavras.

Poetas e tontos se compõem com palavras ${ }^{74}$.

\section{Considerações finais}

Se pensar e poetar não são o mesmo, por outra parte, no caso de Heidegger e Manoel de Barros, não é somente a linguagem o "induvidoso parentesco" que une filosofia e poesia ${ }^{75}$. Tanto no pensar do pensador, quanto no poetar do poeta, avistamos o que os aproxima e os torna tão

${ }^{71}$ HEIDEGGER, "Brief über den Humanismus" (GA 9), p. 319.

${ }^{72}$ HEIDEGGER, Hölderlins Hymne (GA 39), p. 62.

${ }^{73}$ HEIDEGGER, "Brief über den Humanismus" (GA 9), p. 313.

${ }^{74}$ BARROS, O guardador de águas. Rio de Janeiro: Record, 2004, p. 5.

${ }^{75}$ NUNES, Passagem para o poético. Filosofia e poesia em Heidegger. São Paulo: Ática, 1992, p. 266. 
íntimos no que (aparentemente para a ciência, e somente na aparência!) se mostra como tão ínfimo: a busca pelo sentido do in(útil), ou do que supostamente não tem sentido, o nada. A propósito, diz o filósofo:

Falar do nada continua sendo repulsivo e sem-sentido para a ciência. Em troca, ademais do filósofo, pode fazê-lo o poeta. E certamente, não porque a poesia trabalha com menos vigor -como crê o entendimento comum-, senão porque na poesia (somente me refiro à autêntica e grandiosa) impera uma essencial superioridade do espírito frente a toda mera ciência. Desde esta superioridade, o poeta fala sempre como se expressara e invocara o ente pela primeira $\mathrm{vez}^{76}$.

Assim, o "passo atrás" da filosofia de Heidegger e a "poesia das coisas ínfimas" de Manuel de Barros parecem coincidir com este propósito: o de invocar o ente, numa peculiar volta ao originário (ou ao abandono) das coisas, intimamente vinculadas ao sentido do ser. Por isso, ambos concordam que tudo aquilo que se caracteriza como indiferente e banal para os modernos ("tudo aquilo que a nossa civilização pisa e mija em cima", diria o poeta) é o que, em definitivo, deveria interessar à tarefa do pensar e do poetar. Afinal, como diria o filósofo, o inútil é uma experiência nada fácil para os modernos, mas é o que verdadeiramente conduz o homem a si mesmo. Por isso, ambos, pensador e poeta, perseguiram o sentido do inútil, ainda que navegando contra a correnteza de seu tempo: uma época em que predomina a ditadura da utilidade, tal como observava Leminski.

E se, efetivamente, "Poesia é a ocupação da Imagem pelo Ser", como diz o poeta, de modo invertido diria Heidegger sobre a filosofia, em A época da imagem do mundo ${ }^{77}$, que jamais pode ser a ocupação do ser pela imagem. Quando isso ocorre, quando a imagem -bem entendida aqui como a mera objetivação calculadora do real, e que, portanto, difere radicalmente da imagem poética de Barros-, toma o lugar do ser e a linguagem se reduz à mera informação com vistas ao pensar calculador, então, é porque a filosofia chegou ao seu fim e é necessário retomar a tarefa do pensar, adverte Heidegger em $O$ final da filosofia e a tarefa do pensar ${ }^{78}$. O sinal de

\footnotetext{
${ }^{76}$ HEIDEGGER, Einführung in die Metaphysik (GA 40), p. 28-29. (Cf. trad. ao português de Emmanuel Carneiro Leão, Introdução à metafísica. Rio de Janeiro: Tempo Brasileiro, 1999).

77 "Die Zeit des Weltbildes" (GA 5), p. 68-104. (Cf. trad. ao português de Alexandre Franco de Sá, "O tempo da imagem do mundo". In: Caminhos de floresta. Lisboa: Fundação Gulbenkian, 2002). Vale aqui insistir que neste escrito Heidegger faz uma importante aclaração, e até certo trocadilho, entre o sentido da palavra alemã Weltaunschauung e Weltibildes. Segundo Heidegger, ter uma visão de mundo [Weltaunchauung] -que é próprio da metafísica de cada época, já que cada época compreende uma visão ou imagem do mundo-, é totalmente distinto de ver o mundo como imagem [Weltbildes] -que é o próprio da metafísica moderna, especificamente marcada pela ciência e a técnica. Sobre o assunto, ver também: MIRANDA, A. L. y URSUA, N. "Wissenschaft und Technik in Die Zeit des Weltbildes". In: Hans Joachim Petsche (Org.). Topoi der Rationalität: Technizität, Medialität, Kulturalität. Berlin: Trafo, 2010, p. 103-110.

78 "Das Ende der Philosophie und die Aufgabe des Denkens" (GA 14), p. 67-91. (Cf. trad. ao português de Ernildo Stein, "O fim da filosofia e a tarefa do pensamento". In: Conferências e escritos filosóficos. São Paulo: Abril Cultural, 1989).
} 
que a filosofia tenha chegado ao seu fim, posto que se tornou um pensar calculador, pode ser evidenciado no que conjecturava Heidegger nos "Hinos de Hölderlin": talvez, a nossa incapacidade de experienciar o poema não seja por culpa dele (do poema), se não de nós mesmos que, pela exatidão do nosso pensamento enredado na trivialidade da lógica calculadora, já não nos permite experienciar o seu poder ${ }^{79}$. O poder do poema, quiçá, seja mesmo porque a poesia é a ocupação do ser que se manifesta pela palavra. E, como a poesia está guardada nas palavras, como bem disse nosso Manoel de Barros, daí também o poder dos poetas.

Do contexto e do significado da tarefa do pensar para os dias atuais que justifica "para que poetas", tal como insistia Heidegger uma e outra vez ${ }^{80}$, talvez possamos reconhecer a "autêntica e grandiosa" poesia de Manoel de Barros, que, em tempos de utilitarismos, ousou escrever, inclusive, Livro sobre nada. E ele assim o justifica, sem rodeios e sem remorsos: “(...) o nada de meu livro é nada mesmo. É coisa nenhuma por escrito: um alarme para $\mathrm{o}$ silêncio, um abridor de amanhecer, pessoa apropriada para pedras, $\mathrm{o}$ parafuso de veludo, etc, etc". E conclui: "Tudo que use o abandono por dentro e por fora" ${ }^{\prime \prime}$.

Fundamentando-se na filosofia de Martin Heidegger e na poesia de Manoel de Barros, podemos concluir, portanto, que, ainda que guardadas as devidas proporções entre a esfera da filosofia e da poesia, ambos (pensador e poeta) empreenderam seus esforços no pensar que revela: o mais útil é o inútil. Dele deve se ocupar toda forma de pensamento, seja a poiésis ou a poética, seja a filosofia ou a poesia. De tal modo que, enquanto o pensador diz o ser, o poeta nomeia o sagrado ${ }^{82}$. Não por acaso, revela Manoel de Barros:

(...)

Todas as coisas apropriadas ao abandono me religam a Deus.

Senhor, eu tenho orgulho do imprestável!

$(\mathrm{O} \text { abandono me protege. })^{83}$

\section{Referências}

BARROS, M. de. Livro sobre nada. $3^{\text {o }}$ edição. Rio de Janeiro: Record, 1996.

. Meu quintal é maior que o mundo. Rio de Janeiro: Objetiva, 2015

. O guardador de águas. Rio de Janeiro: Record, 2004.

\footnotetext{
${ }^{79}$ HEIDEGGER, Hölderlins Hymne (GA 39), p. 20.

${ }^{80}$ Veja-se, sobretudo, “Wozu Dichter?" (GA 5). Também, “Brief über den Humanismus" (GA 9).

${ }^{81}$ BARROS, Poesia completa, p. 327.

${ }^{82}$ HEIDEGGER, “Nachwort zu "“Was ist Metaphysik"”, (GA 9), p. 312. (Cf. trad. ao português de Enio Paulo Giachini e Ernildo Stein,"Posfácio a "O que é metafísica?". In: Marcas no Caminho. (Wegmarken). Petrópolis, RJ: Vozes, 2008).

${ }^{83}$ BARROS, Livro sobre nada, Rio de Janeiro: Record, 1996, p. 57.
} 
_.. O livro das ignorãças. Rio de Janeiro: Record, 1993.

. Poesia completa. São Paulo: Leya, 2010.

- Tratado geral das grandezas do ínfimo. Rio de Janeiro: Record, 2001.

Só dez por cento é mentira: a desbiografia de Manuel de Barros. (Documentário).

Direção de Pedro César. Brasil: Artezanato eletrônico, 81'16", 2008.

BISPO do ROSÁRIO, A. "Talheres". In: Itaú Cultural de Arte e Cultura Brasileiras. Disponível em: http://enciclopedia.itaucultural.org.br/obra35996/talheres. Acesso em: Abr. de 2018.

CASTRO SULINO, M. R. de; MIRANDA, A. L. "Pensar o ínfimo: aproximações entre o caráter (in)útil da técnica e o poético". In: Anais do VII Simpósio Nacional de Ciência, Tecnologia e Sociedade (ESOCITE/2017). Brasília: Finatec/UNB, 05-07 de Outubro de 2017, p. 1-15.

HEIDEGGER, M. "Der Ursprung des Kunstwerks". “Die Zeit des Weltbildes". Wozu Dichter?". In: Holzwege. (GA 5). Frankfurt am Main: Klostermann, 1984.

."Die Frage nach der Technik". "Wissenschaft und Besinnung". "Was heißt Denken?". “...dichterisch wohnet der Mensch...". "Bauen Wohnen Denken”. "Das Ding". In: Vorträge und Aufsätze. (GA 7). Frankfurt am Main: Klostermann, 2000.

"Nachwort zu "“Was ist Metaphysik'". "Brief über den Humanismus". In: Wegmargen. (GA 9). Frankfurt am Main: Klostermann, 1976.

. Identität und Differenz. (GA 11). Frankfurt am Main: Klostermann, 2006.

"Schöpferische Landschaft: Warum bleiben wir in der Provinz?" In: Aus der Erfahrung des Denkens. (GA 13). Frankfurt am Main: Klostermann, 1983.

. "Das Ende der Philosophie und die Aufgabe des Denkens". In: Zur Sache des Denkens. (GA 14). Frankfurt am Main: Klostermann, 2007.

.“Vier Seminare (Le Thor/1969, Zäringhen/1973)”. In: Seminare. (GA 15). Frankfurt am Main: Klostermann, 1986.

"Gelassenheit". In: Reden und andere Zeugnisse eines Lebensweges. (GA 16). Frankfurt am Main: Klostermann, 2000.

_. Hölderlins Hymne. "Germanien" und "Der Rhein". (GA 39). Frankfurt am Main: Klostermann, 1980.

. Einführung in die Metaphysik. (GA 40). Frankfurt am Main: Klostermann, 1983.

. Bremer und Freiburger Vorträge. (GA 79). Frankfurt am Main: Klostermann, 1994.

. Zollikoner Seminare. (GA 89). Frankfurt am Main: Klostermann, 1994.

. Lingua de tradição e língua técnica. Trad. de Mário Botas. Passagens: Lisboa, 1995.

LEMINSKI, P. Ensaios e anseios crípticos. Campinas: Editora da Unicamp, 2012.

LOPARIC, Z. "Ética e finitude". In: Benedito Nunes (Ed.). A Crise do pensamento. Belém: Editora da UFPa, 1994, p. 37-122.

LIMA, T. Diário de flores ou lamento de um blue. Natal: Lucgraf, 2010. 
MERLEAU-PONTY, M. O olho e o espírito. Trad. de Paulo Neves e Maria Ermantina Galvão Gomes Pereira. São Paulo: Cosac \& Naify, 2004.

MIRANDA, A. L. Técnica y ser en Heidegger. Salamanca: Universidad de Salamanca, 2017.

__ ¿Una ética para la civilización tecnológica? Posibilidades y límites del principio de la responsabilidad de Hans Jonas. Alemanha/Espanha: Lap Lambert/EAE, 2012.

MIRANDA, A. L.; URSUA, N. "Wissenschaft und Technik in Die Zeit des Weltbildes". In: Hans Joachim Petsche (Org.). Topoi der Rationalität: Technizität, Medialität, Kulturalität. Berlin: Trafo, 2010, p.103-110.

NUNES, B. “Heidegger e a poesia". In: Natureza Humana 2 (1). São Paulo, 2000, p. 103-127.

. Passagem para o poético. Filosofia e poesia em Heidegger. São Paulo: Ática, 1992.

ORDINE, N. La utilidad de lo inútil. Trad. de Jordi Bayod. Barcelona: Acantilado, 2013.

SAFRANSKI, R. Un maestro de Alemania. Martin Heidegger y su tiempo. Trad. de Raúl Gabás. Barcelona: Fábula, 2003.

Endereço da Autora:

Universidade Federal do Rio Grande do Norte (UFRN/ECT)

Campus Universitário

Av. Senador Salgado Filho, s/n - Lagoa Nova

59078-970 Natal - RN

angelalmiranda@gmail.com 